\title{
Protection for Workers in The Fire Service Palembang City
}

\author{
Ahmad Yani Kosali ${ }^{*}$, Dita Marisa Putri ${ }^{1}$, Syaiful Sahri ${ }^{2}$ \\ ${ }^{1}$ Public Administration Science, Satya Negara University, Palembang, Indonesia \\ ${ }^{2}$ Economic Department, Tridinanti University, Palembang, Indonesia
}

\begin{abstract}
In the implementation of national development, the workforce has a very important role and position as actors and development goals and is required to participate and play an active role with entrepreneurs in efforts to improve and improve the nation's standard of living by increasing production and work productivity. Peace of mind and tranquility of workers can only be achieved if employers and workers can understand and live up to their respective rights and obligations so as to foster mutual understanding, mutual respect, and respect without neglecting the values of rationality and accountability. The development of the manpower sector as part of efforts to develop human resources is an integral part of national development as the practice of Pancasila, and the implementation of the 1945 Constitution, is directed at increasing human dignity, dignity and capabilities, as well as confidence in oneself in in order to create a prosperous, just and prosperous society both materially and spiritually.
\end{abstract}

Keywords: Protection, Workers, and Productivity.

*Corresponding Author:

E-mail: yanikosali@gmail.com (Ahmad Yani Kosali)

Public Administration Science, Satya Negara University, Palembang, Indonesia

\section{INTRODUCTION}

In 1977 an important milestone was obtained with the issuance of Government Regulation (PP) Number 33 of 1977 concerning the Implementation of the Social Insurance Program for Workers (ASTEK), which required every employer/private entrepreneur and StateOwned Enterprises/BUMN to participate in the ASTEK program. Government Regulation No. 34/1977 on the Establishment of an ASTEK Organizer was also issued, namely Perum Astek.

The next important milestone was the enactment of Law Number 3 of 1992 concerning Labor Social Security (JAMSOSTEK). And through Government Regulation No. 36/1995 stipulation of PT. Jamsostek as the Social Security Administering Body for Workers. According to (Asyhadie, 2007), The Jamsostek program provides basic protection to meet the minimum needs for workers and their families, by providing certainty of the ongoing flow of family income as a partial or full replacement of lost income due to social risks.

Furthermore, at the end of 2004, the Government also issued Law Number 40 of 2004 concerning the National Social Security System, which was related to the amendments to the 1945 Constitution with changes to article 34 paragraph 2, where the People's Consultative Assembly (MPR) has ratified the amendment, which now reads: "The state develops a Social Security System for all the people and empowers the weak and underprivileged in accordance with human dignity". The benefits of this protection can provide workers with a sense of security, so they can concentrate more on increasing work motivation and productivity.

Jamsostek or social security for workers is a government program, to
Journal Homepage:

http://ejournal.undwi.ac.id/index.php/jsds
Copyright (C) 2021 Dwijendra University. All right reserved. 
provide basic protection for workers, in order to maintain their dignity as human beings, in overcoming the risks that arise in working relationships. Jamsostek provides assurance and protection against socioeconomic risks caused by work accidents, disability, illness, old age and death. (Darwan, 2000).

It is natural, that humans are married and are obliged to bear their families. Therefore, welfare is developed not only for the workers themselves, but also for their families in order to improve the welfare of the community in a broad sense, which must be maintained, including when workers lose part or all of their income as a result of social risks, including: work accidents, illness, death, and old age.

It is natural, that humans are married and are obliged to bear their families. Therefore, welfare is developed not only for the workers themselves, but also for their families in order to improve the welfare of the community in a broad sense, which must be maintained, including when workers lose part or all of their income as a result of social risks, including: work accidents, illness, death, and old age.

\section{Literature Review}

Workers as implementers of development must have their rights guaranteed, their obligations regulated and their usefulness developed. In the regulation of the Minister of Manpower Number: PER-04 / MEN / 1994, the definition of Manpower is every person who works for a company that is not yet obliged to take part in the Manpower Social Security Program because of the phasing out of participation.

According to (Damanik, 2006), Health Care Insurance is a guarantee as an effort to overcome and prevent health problems that require examination, treatment, and / or care including pregnancy and childbirth. Health maintenance is intended to increase the productivity of the workforce so that they can carry out their duties as well as possible and constitute a health effort in the field of healing. Therefore, they feel the need to be given protection, maintenance, and improvement of their welfare, thereby creating a sense of security at work.

The safety requirements include:

a. Prevent and reduce accidents.

b. Prevent, reduce and extinguish fires.

c. Prevent and reduce explosion hazard.

d. Provide an opportunity or a way of escape in the event of a fire or other dangerous events.

e. Provide assistance in accidents.

f. Provide personal protective equipment to workers.

g. Obtain adequate and appropriate information.

h. Maintain good temperature and humidity.

i. Maintain cleanliness, health and order. (Husni, 2003).

\section{Type of Work Protection}

Theoretically, there are three types of work protection, namely:

\section{Social Protection or Occupational Health.}

According to (Hardijan, 2004), Occupational health is a type of Social Protection because the provisions concerning occupational health are related to social society, namely regulations that intend to impose restrictions on the power of employers to treat workers/laborers "as they wish" without regard to applicable norms, without regard to views workers / laborers as creatures of God who have human rights.
Journal Homepage:

http://ejournal.undwi.ac.id/index.php/jsds
Copyright (C) 2021 Dwijendra University. All right reserved. 
Because of its nature, which intends to impose "restrictions" on the provisions of Social Protection in Law Number 13 of 2003, Chapter X Article 68 and so on are "coercive", not regulated. Due to the coercive nature of the provisions of this Social Protection Law Number 13 of 2003, the legislators deem it necessary to explain that the provisions relating to this Social Protection constitute "general law" (Publiek-rechtelijk) with criminal sanctions. This is due to the following reasons:

1. The rules contained therein are not meant to protect the interests of a single person, but are social rules.

2. Indonesian workers / laborers generally do not have the understanding or ability to protect their own rights. (Miru, 2010).

\section{Technical Protection or Work Safety.}

In contrast to other work protections which are generally determined for the benefit of workers/laborers, this Occupational Safety does not only provide protection to workers/laborers, but also to employers and the government.

1. For workers / laborers, the existence of a Work Safety Protection Guarantee will create a peaceful working atmosphere, so that workers / laborers can focus on their work as much as possible without worrying that at any time there will be work accidents.

2. For entrepreneurs, the existence of work safety arrangements in their companies will be able to reduce the occurrence of accidents that can result in employers having to provide Social Security.

3. For the government (and the community), with the existence and compliance of Occupational Safety regulations, what is planned by the government for the welfare of the community will be achieved by increasing the company's production, both in quality and quantity. (Triyanto, 2004).

\section{Economic Protection or Social} Security.

Workers' Social Security is a protection for workers in the form of compensation in the form of money as a substitute for part of lost or reduced income and services as a result of events or conditions experienced by workers in the form of work accidents, illness, pregnancy, childbirth, old age, and die.

Workers' Social Security as regulated in Law Number 3 of 1992 are:

It is the right of every worker which is also the obligation of the employer. In essence, the Manpower Social Security Program is intended to provide certainty of the ongoing flow of family income which is partially lost.

In addition, the Manpower Social Security Program has several aspects, including:

a. Provide basic protection to meet the minimum living needs for workers and their families.

b. It is an appreciation for the workforce to educate workers' independence, so that workers do not have to ask for the mercy of others if there are risks in the employment relationship such as: work accidents, illness, old age and others.

\section{Types of Labor Social Security.}

\section{Work Accident Insurance}

Work accidents and occupational diseases are risks faced by workers who do work. To overcome the loss of part or all of 
his income caused by death or disability due to work accidents, both physical and mental, it is necessary to have Work Accident Insurance.

\section{Death Guarantee}

Workers who die not due to work accidents will result in loss of income, and greatly affect the socio-economic life of the bereaved family. Therefore, death insurance is needed in an effort to ease the burden on the family, both in the form of funeral costs and financial compensation.

\section{Old Age Guarantee}

Old age can result in cut off wages because they are no longer able to work. As a result of the cut in wages, it can cause concern for the workforce and affect employment while still working, especially for those with low incomes. Old Age Security provides certainty of receipts that are paid at once and or periodically when the workforce reaches the age of 55 (fifty five) years or fulfills these requirements.

\section{Health Care Insurance}

Health Maintenance is intended to increase the productivity of the workforce, so that they can carry out their duties as well as possible and constitute a health effort in the field of healing (curative). (Darwan, 2000).

\section{METHODS}

In carrying out this research, there are two approaches used, namely the normative or doctrinal juridical approach and the empirical or non-doctrinal juridical approach. (Amirudin, Asikin, 2004).

\subsection{Normative Juridical Approach (Doctrinal)}

Is an approach that views law as a doctrine or a set of normative rules (law in book), (Soekanto, 2014). This approach is carried out through an effort to study or research legal literature. In this case, the researcher analyzes legal principles, legal norms and opinions of scholars.

\subsection{Empirical Juridical Approach (Non Doctrinal)}

In the empirical (non-doctrinal) juridical approach, law is conceptualized as a social institution that is actually related to other social variables. If law as an empirical social phenomenon is studied as an independent variable / cause (independent variable) that causes influence and consequences on various aspects of social life, the study is a sociological legal study (socio-legal research). However, if law is studied as a dependent variable that arises as a result of various forces in social processes, the study is a sociological study of law (sociology of law).

\section{RESULT AND DISCUSSION}

\subsection{Protection for Workers at the} Palembang City Fire Service.

From the results of an interview with Mr. Ahmad who is the Head of Operations of the Palembang City Fire Department, he explained that the functions of the Fire Department are:

1. Formulation of technical policies in the field of fire management as well as aid and rescue against other disasters.

2. Prevention and response to fire hazards as well as aid and rescue from other disasters.

3. First aid, rescue as a result of fire and other disasters, including the implementation of ambulance or evacuation services.

4. Supervision and control of the circulation of flammable goods and materials.

5. Procurement of water sources and other materials in the context of fire prevention. 
6. Community empowerment in the field of community prevention and control efforts.

7. Research on materials related to laboratory fire prevention issues.

8. Coordination and technical guidance for fire fighting units of government, private or community agencies.

9. Research and investigate the causes of fires and disasters, in collaboration with other agencies.

10. Training and improving the skills of firefighters in dealing with fires as well as aiding and rescuing other disasters.

11. Management of technical and administrative support.

12. Technical guidance on the implementation of the activities of the Fire Service Sub-dept.

As for the daily tasks at the Palembang City Fire Service, they are carried out by employees consisting of civil servants and daily / temporary employees who are members of fire rescue teams and other disasters. For this reason, in carrying out their duties, they need expertise and physically / physically tough considering the very dangerous risks of the work they do.

Physical and spiritual freshness is a supporting factor to increase one's productivity at work. This freshness starts from entering the job and continues to be maintained during work, even after stopping work. Physical and spiritual fitness is not only a reflection of physical and mental health, but also a description of the harmony of a person's adjustment to his work, which is greatly influenced by his abilities, experience, education and knowledge. Humans and workloads as well as factors in the work environment are an inseparable whole. Such a unit is called a dynamic balance wheel. If this balance is not favorable, unstable conditions will occur and cause health problems, even disease, disability and death.

To prevent health and work problems, there are several efforts that can be done so that workers / laborers remain productive and get Occupational Safety Protection Guarantees, namely health checks before work, periodic health checks, namely for evaluation and education about health and safety to workers. Another thing is counseling before work so that they know and obey the rules and be more careful.

In principle, the main capital in an effort to prosper the workers / laborers, not only lies in the level of income (wages) provided by the company. However, other factors have quite an important role, namely the attention or protection from employers related to health problems and the existence of work safety guarantees.

From the results of research at the Palembang City Fire Service, it can be seen that there are two groups of workers, namely the group of workers who have become Civil Servants (PNS) which of course has guaranteed work guarantees and protection, for example in terms of health for those civil servants, their health insurance is already in place under ASKES. However, what about those who work but are not yet civil servants, what is the form of protection for them?

From the results of research at the Palembang City Fire Service, it can be seen that of the 70 employees at the agency not all of them have the status of Civil Servants, there are still 11 workers / laborers whose status is still daily workers. And to carry out daily tasks in preventing fires in the city of Palembang, workers / laborers whose status is still daily workers are given work protection in the form of being included as Jamsostek participants.
Journal Homepage:

http://ejournal.undwi.ac.id/index.php/jsds
Copyright (C) 2021 Dwijendra University. All right reserved. 
Before we discuss further about the form of protection with PT. Jamsostek in terms of Work Safety Guarantee for freelancers in the Palembang City Fire Service agency, will be described first about the working relationship between employers and workers / laborers and the importance of protecting each worker / laborer.

The form of the working relationship between the entrepreneur and the worker for a certain time is based on the agreement of both parties as stated in the work agreement as the basis for the existence of a working relationship between the two. In the work agreement agreed by both parties, it forms a working relationship that gives birth to the rights and obligations of each party, in which the rights of the entrepreneur are obligations. Vice versa, the rights of workers are the obligations of employers. The work agreement also includes the amount of wages, the type of work that must be done by the worker for a certain time. The period of time that must be taken to complete the work as well as the procedure for termination of employment that is applied, because this termination of employment has been agreed in the work agreement, in which the method of ending this employment relationship is terminated by law.

Basically, certain types of work for a certain period of time can be carried out with workers for a certain time if they fulfill all the requirements, both formal and material, as regulated in Article 59 of Law Number 13 of 2003, namely:

a. Jobs that are once completed or temporary in nature;

b. Work which is estimated to be completed in a not too long time and a maximum of 3 (three) years;

c. Seasonal work; or d. Work related to new products, new activities, or additional products that are still being tested or explored.

Certain time workers are held for a maximum of 2 (two) years and may only be extended 1 (one) time for a maximum of 1 (one) year. However, in practice many outsourced workers are bound by work contracts for more than 2 (two) years. Renewal of certain time workers may only be carried out 1 (one) time and a maximum of 2 (two) years, so the total working period of a contract worker in the company is 5 (five) years, but that period may not be stated directly in one time job. Certain, because they have to go through the stages of extension and renewal of the work agreement first. After the expiration of the renewal period, the company is not allowed to bind the worker with the worker for a certain time again. Within the Palembang City Fire Service Agencies, workers for a certain time are known as daily casual workers, who usually have positions in the operational team, within the Palembang City Fire Service employs 11 (eleven) daily casual workers who are not Civil Servants to be placed in the operational squad.

Every human being basically must face risks, both risks to life and property. As well as the risk of legal liability. Risk is basically uncertainty that causes economic losses. Ways to overcome risk can be taken: avoid, prevent, divert, and accept. Of the four ways, the most profitable is to transfer risk by way of insurance, including in this case health insurance. Because the purpose of insurance is to transfer risk from the insured to the insurer. Health insurance includes the insured, the insurer and the Health Service Provider (PPK).

Judging from the purpose, insurance is divided into two, namely:
Journal Homepage:

http://ejournal.undwi.ac.id/index.php/jsds
Copyright (C) 2021 Dwijendra University. All right reserved. 


\section{a. Social Insurance / Mandatory (Government)}

b. Commercial Insurance (Private).

Social Insurance (mandatory) aims to provide social security to the public or some members. certain communities, which are mandatory based on laws and regulations, are carried out by the state, thus, directly involving the role of the state. Meanwhile, commercial insurance aims to make a profit, is voluntary based on an agreement between the insured and the insurer, so that the terms and principles of legal agreement in general can be carried out by the private sector, as well as the state. PT (Persero) Indonesian Health Insurance and PT (Persero) Labor Social Security including Social Insurance (mandatory).

Based on the foregoing, health insurance is an important matter for people's lives, so that a National Health Insurance Law is immediately drafted, both regulating Social Insurance (mandatory), as well as Commercial Insurance with the responsibility of the insurer to the insured including: prevention, improvement, healing and rehabilitation. This is intended so that the Indonesian people obtain maximum health care services and can achieve an increase in healthy life.

Workers' Social Security is a form of protection and welfare for workers that must be provided by employers, including workers for a certain period of time. With the JAMSOSTEK Program, it can increase productivity and work quality so as to create conducive conditions for the development of the business world.

In order to create Social Protection / Security to improve welfare and work protection as well as to fulfill its obligations, the agency in Palembang City, namely the Palembang City Fire Service entered into an agreement with PT.
Jamsostek in terms of work safety guarantees for freelancers in the Palembang City Fire Service agency because in this case PT Jamsostek is the organizer of the social security for workers which has been regulated in Government Regulation No. 14 of 1993, while the Civil Servants themselves are included in the Health Insurance is not through Jamsostek.

The participation of the workforce in national development is increasing along with the various challenges and risks it faces. Therefore, it is necessary for workers to be given protection, maintenance and improvement of their welfare, so that in turn they will be able to increase national productivity. This is an obligation that must be carried out by the Palembang City Fire Service because in article 4 paragraph (1) of Law Number 3 of 1992 it says that the Labor Social Security Program as referred to in article 3 must be carried out by every company for workers who do work. in the employment relationship in accordance with the provisions of the law. Then, coupled with the Government Regulation Number 14 of 1993 concerning the Implementation of the Workforce Social Security Program in article 2 paragraph (3) it is stated that entrepreneurs who employ 10 (ten) or more workers, or pay a minimum wage of Rp. 1.000.000,- (one million rupiah) a month, must include its workforce in the Manpower Social Security Program as referred to in paragraph (1).

From the description above, it can be seen that in terms of labor social security, the Palembang City Fire Service then stated that the form of protection for workers or laborers (daily/honorary employees) at the Palembang City Fire Service was through the Labor Social Security Program (Social Security).
Journal Homepage:

http://ejournal.undwi.ac.id/index.php/jsds
Copyright (C) 2021 Dwijendra University. All right reserved. 
The form of protection from social security for workers / laborers of the Palembang City Fire Service is related to: Work Accident Insurance (JKK), namely:

a. The company guarantees the transportation needed for workers who have an accident at work to the hospital or to their homes.

b. In the event that a worker gets an accident due to carrying out the duties as mentioned in Law No. 3 of 1992 and other provisions that result in a worker being temporarily unable to work, compensation as referred to in the Accident Law above or to the worker is given. workers are given compensation as follows:

1. 100 (one hundred) percent of the last wage he received for the first 18 (eighteen) months of his inability to work.

2. 50 (fifty) percent of the last wage he received after 18 (eighteen) months until his inability to work ends.

3. In the event that the worker is unable to work permanently after passing the period referred to in number (1), it will be processed by the Health Advisory Council (MPK) with a maximum decision in the twenty-fourth month.

c. The company bears all medical expenses and care for workers who have an accident due to carrying out their duties, from the time the accident occurs until the end of the temporary condition of the worker in question being unable to work.

d. A worker who gets a work accident and results in a permanent disability of one of his limbs and or reduced function according to a doctor's statement, is given compensation of 2 (two) times the monthly wage in addition to the provisions of Law No. 3 of 1992 and Government Regulation No. 14 of 1993.

e. The provisions as referred to in letter $\mathrm{d}$ shall not apply if the accident occurs as a result of the intention of the worker concerned.

According to (Markanen, 2006), Old Age Guarantee (JHT)

a. Worker Program and Insurance Program.

The company provides savings and insurance programs for workers whose benefits will be received at once by workers upon termination of employment. For now, the Palembang City Fire Department, in terms of the Insurance Program, is directly organized by PT. Social Security.

b. Health Financing Program.

The company holds a Health Service Program for retired workers with an insurance/funding system. The Service/Funding Financing Program is implemented no later than 1 (one) year since the enactment of the PKB whose premiums are borne by the company and the workers/laborers.

c. Pension Fund Program

All workers who are appointed at the age of 18 (eighteen) years to 40 (forty) years after being appointed as workers, are registered as Participants of the Pension Fund Program. Employers facilitate the Trade Unions / FSPPB to obtain the widest possible information regarding the management of pension funds, including placing 1 (one) representative of the Trade Unions / FSPPB as a member of the Pension Supervisory Board.
Journal Homepage:

http://ejournal.undwi.ac.id/index.php/jsds
Copyright (C) 2021 Dwijendra University. All right reserved. 


\subsection{Death Insurance (JK)}

In the event that a worker dies as a result of an accident as referred to in letter $\mathrm{b}$ and or the worker dies suddenly at the workplace, the bereaved family shall be paid a compensation of 72 (seventy) months wages including compensation for death due to work accidents from PT. Jamsostek or Insurance Company appointed by the company. What is meant by work accident and sudden death at work is as stipulated in the provisions of the applicable laws and regulations. (H. S, 2002).

\subsection{Health Care Insurance (JPK)}

According to (Sastrio, 2015), Health Care Insurance is a facility provided by the company in examining and maintaining the health of workers and their families. Health checks and maintenance of workers / laborers are carried out by medical personnel owned by the company or appointed by the company.

From the results of research on the insurance agreement at PT. Jamsostek with the Palembang City Fire Department, the amount of insurance to be paid is in accordance with the provisions of Government Regulation No. 14 of 1993, which are as follows:

1. Work Accident Insurance (JKK) is $0.24 \%$ of the total salary of honorary employees earned per month. As for the Palembang City Fire Department, there were 11 participants with a salary of Rp. 400.000,- so the amount of work accident insurance that must be paid is Rp. 960,- per person. So, the total amount for 11 people is Rp. 10.560,-

2. Death Security (JKM) is $0.30 \%$ of the total salary of honorary employees earned per month. As for the Palembang City Fire Department, there were 11 participants with a salary of Rp. 400.000 ,- so the amount of death insurance to be paid is Rp. 1.200,- per person. So, the total amount for 11 people is Rp. 13.200,-

3. Old Age Security (JHT) is $3.70 \%$ of the total salary of honorary employees earned per month. As for the Palembang City Fire Department, there were 11 participants with a salary of Rp. 400.000,- so the amount of old-age insurance to be paid is Rp. 22.800,- per person. So, the total amount for 11 people is Rp. 250.800,-

4. Health Care Insurance (JPK) $3.00 \%$ for those who are single and $6.00 \%$ for those who already have a family from the total salary of honorary employees earned per month. As for the Palembang City Fire Department, there were 11 participants with a salary of Rp. 400.000,- consisting of 6 single and 5 married, so the amount of health care insurance that must be paid is:

a. Single : Rp. 12.000,- per person x $6=$ Rp. 72.000,-

b. Married : Rp. 24.000,- per person x $6=$ Rp. 120.000,-

So, the total amount for 11 people is Rp.192.000,-

So that from all the Workforce Social Protection Programs that must be paid by the Palembang City Fire Department to PT. Jamsostek in each month is Rp. 465.760, (four hundred and sixty five thousand seven hundred and sixty rupiah).

As for after the participant is registered as a Jamsostek participant, in this case an employee of the Palembang City Fire Department who is not a civil servant, he will get the following rights:

1. Get insurance compensation if the claim submitted from PT. Jamsostek, if the administration has been declared complete in accordance with Law
Journal Homepage:

http://ejournal.undwi.ac.id/index.php/jsds
Copyright (C) 2021 Dwijendra University. All right reserved. 
Number 3 of 1992 in conjunction with its Implementing Regulations.

2. Entitled to proof of premium payment from PT Jamsostek for the contributions or premiums that have been paid. (Uwiyono, 2014).

However, before the Jamsostek participants, in this case the employees of the Palembang City Fire Department who are not civil servants, get their rights, the participants also have an obligation in the form of paying contributions or premiums to PT. Jamsostek is in accordance with the agreement and notifies or reports the number of daily temporary / freelance workers if there are changes.

Likewise with PT. Jamsostek has the following rights and obligations:

1. Obligations of PT Jamsostek

For PT Jamsostek in this case the insurance provider has obligations that must be carried out in the form of:

a. Obliged to pay insurance compensation if there is a claim from the insured if the administration has been declared complete in accordance with Law Number 3 of 1992 in conjunction with its Implementing Regulations.

b. Obliged to submit proof of premium payment to the Palembang City Fire Department. In this case, after the end of the contract agreement, PT Jamsostek is obliged to send proof of premium payment to the Palembang City Fire Department.

2. Rights of PT Jamsostek

In this case, the insurance provider, which in this study is PT Jamsostek, has the right to receive payment of contributions or premiums from the Palembang City Sanitation Service. (Thoga, 2010).

\section{CONCLUSION}

From the results of the research described above, it can be concluded that:

1. Whereas the form and implementation of protection for workers / laborers at the Palembang City Fire Service is through the Social Security Program for Workers (Jamsostek) which includes:

a. Work Accident Insurance (JKK).

b. Old Age Guarantee (JHT).

c. Death Insurance (JK).

d. Health Care Insurance (JPK).

2. Whereas the basic factor so that protection for workers/laborers at the Palembang City Fire Service can be implemented, in this case against workers/laborers whose status is not civil servants or only as daily workers is due to the very high level of legal awareness.

\section{REFERENCES}

Amirudin, Asikin, Z. (2004). Pengantar Metode Penelitian Hukum. Raja Grafindo Persada.

Asyhadie, Z. (2007). Hukum Kerja (Hukum Ketenagakerjaan Bidang Hubungan Kerja). Raja Grafindo Persada.

Damanik, S. (2006). Outsourcing \& Perjanjian Kerja menurut UU Nomor 13 Tahun 2003 tentang Ketenagakerjaan. DSS Publishing.

Darwan, P. (2000). Hukum Ketenagakerjaan Indonesia. PT. Citra Aditya Bakti.

H. S, S. (2002). Pengantar Hukum Perdata Tertulis. Sinar Grafika.

Hardijan, R. (2004). Hukum Ketenagakerjaan. Ghalia Indonesia.

Husni, L. (2003). Pengantar Hukum Ketenagakerjaan Indonesia. Raja Grafindo Persada.

Markanen, P. (2006). Keselamatan dan Kesehatan Kerja Di Indonesia. International Labour Organization.

Miru, A. (2010). Hukum Kontrak Perancangan Kontrak. Raja Grafindo Persada.
Journal Homepage:

http://ejournal.undwi.ac.id/index.php/jsds
Copyright (C) 2021 Dwijendra University. All right reserved. 
Journal of Sustainable Development Science

Vol. 3, No. 2, December 2021, pp. 45-55

e-ISSN: 2715-9140 | p-ISSN: 2722-919X

Moleong, L. (2005). Metode Penelitian Kualitatif. PT. Remaja Rosdakarya.

Sastrio, A. (2015). Prospek Dan Tantangan Terhadap Peran Jamsostek Dalam Melindungi Dan Meningkatkan Kesejahteraan Pekerja. Www.Hukumonline.Com. www.hukumonline.com

Soekanto, S. (2014). Penelitian Hukum Normatif. PT. Raja Grafindo Persada.

Thoga, M. S. (2010). Jaminan Sosial dan Perkembangannya. Www.Kompas.Com.

Triyanto, D. (2004). Hubungan Kerja di
Perusahaan Jasa. Mandar Maju.

Uwiyono, A. (2014). Asas-asas Hukum Perburuhan. Rajawali Pers.

Indonesia. Undang-undang Jaminan Sosial Tenaga Kerja Nomor 3 Tahun 1992.

Indonesia. Undang-undang Ketenagakerjaan Nomor 13 Tahun 2003.

Indonesia. Undang-undang Badan Penyelenggara Jaminan Sosial Nomor 24 Tahun 2011.

Indonesia. Peraturan Pemerintah Tentang Penyelenggaraan Jaminan Sosial Tenaga Kerja Nomor 14 Tahun 1993
Journal Homepage:

http://ejournal.undwi.ac.id/index.php/jsds
Copyright (C) 2021 Dwijendra University. All right reserved. 